\title{
PENGEMBANGAN PERANGKAT PEMBELAJARAN PROJECT-BASED LEARNING UNTUK MEMBEKALI FOUNDATIONAL KNOWLEDGE DAN MENINGKATKAN SCIENTIFIC LITERACY
}

\author{
Ricka Tesi Muskania dan Insih Wilujeng \\ Program Pascasarjana Universitas Negeri Yogyakarta \\ email: ricka.muskania@gmail.com dan insihuny@yahoo.co.id
}

\begin{abstract}
Abstrak: Penelitian bertujuan mengetahui: (1) kelayakan perangkat pembelajaran IPA berbasis projectbased learning, (2) pengaruh penerapan perangkat pembelajaran IPA berbasis project-based learning terhadap keterbekalan digital/ICT literacy, (3) penerapan perangkat pembelajaran IPA berbasis projectbased learning terhadap scientific literacy peserta didik SMP. Penelitian ini merupakan penelitian dan pengembangan dengan menggunakan model Borg \& Gall dengan prosedur (1) studi pendahuluan, (2) desain produk, (3) validasi, (4) ujicoba dan revisi produk hingga menghasilkan produk akhir. Pengumpulan data dengan teknik observasi, angket, dan tes, sedang analisis data dengan teknik statistik deskriptif. Hasil penelitian ini adalah kelayakan perangkat pembelajaran IPA berbasis project-based learning yang dihasilkan memperoleh kriteria baik sekali. Keterbekalan foundational knowledge khusus digital/ICT literacy sebesar 98,29\%. Kriteria baik sekali diperoleh untuk peningkatan scientific literacy pesertadidik setelah mengikuti pembelajaran menggunakan perangkat pembelajaran IPA berbasis project-based learning dengangain score sebesar 15,37. Hasil uji independent-sample t test menunjukkan bahwa perangkat pembelajaran berbasis project-based learning memberikan pengaruh signifikan terhadap scientific literacy peserta didik.
\end{abstract}

Kata Kunci: perangkat pembelajaran IPA, project-based learning, digital/ICT literacy, scientific literacy

\section{DEVELOPING A PROJECT-BASED SCIENCE LEARNING KIT TO PROVIDE FOUNDATIONAL KNOWLEDGE AND IMPROVE SCIENTIFIC LITERACY}

\begin{abstract}
This study aims to reveal (1) the feasibility of the project-based science learning kit, (2) the influence of project-based science learning kit on the digital/ICT literacy, and (3) the influence of project-based science learning kit on the improvement of scientific literacy of junior high school students. It adopted research and development $(\mathrm{R} \& \mathrm{D})$ design developed by Borg \& Gall consisting of (1) preliminary study, (2) product design, (3) validation, and (4) tryout and revision, until the final product was fully developed. Data were collected through observation, questionnaires, and test, then analysed using descriptive statistics method. The results show that the kit can be considered as very good. The provision of foundational knowledge in particular digital/ICT literacy is as much as $98.29 \%$. The scientific literacy can be categorized "very good". This is the result of students' involvement in the teaching activities implementing the project-based science teaching kit (the score is 15.37). The result of independent-sample $t$ test shows that the project-based science learning kit gives a significant effect on the improvement of the scientific literacy of junior high school students.
\end{abstract}

Keywords: science learning kit, project-based learning, digital/ICT literacy, scientific literacy

\section{PENDAHULUAN}

Berdasarkan Education for All Global Monitoring Report 2012 yang dikeluarkan oleh UNESCO pendidikan Indonesia berada di peringkat ke-64 dari 120 negara. Hal ini disebabkan karena banyak materi uji yang tidak terdapat dalam kurikulum Indonesia (Mendikbud, 2013:2) terutama yang berkaitan dengan kemajuan teknologi dan informasi. Peningkatan kualitas peserta didik dapat dilakukan dengan meningkatkan kualitas pendidikan yang mengacu pada ketercapaian kompetensi digital/ICT literacy yang dapat digunakan di era global sehingga generasi Indonesia mampu bersaing di dunia internasional. Hal ini yang menyebabkan perubahan pada standar nasional pendidikan yang berupa standar isi, 
standar proses, standar kompetensi lulusan, dan standar penilaian yang mengarah pada pembelajaran yang berpusat pada peserta didik (student oriented) yang mengembangkan pola pembelajaran interaktif, jejaring, kelompok, berbasis multimedia, dan kritis yang berbasis pendekatan/ metode ilmiah (scientific approach) dan diukur melalui penilaian otentik (authentic assessment) yang tercermin pada pelaksanaan Kurikulum 2013 sehingga diharapkan peserta didik menguasai kompetensi yang diharapkan pada abad XXI meliputi foundational knowledge (to know), meta knowledge (to act) dan humanistic knowledge (to value) (Kereluik, 2013:130).

Foundational knowledge terdiri dari tiga subkategori yaitu cross-disciplinary, core content knowledge, dan digital/ICT literacy. Digital/ICT literacy merupakan kemampuan melek digital dan informasi komunikasi serta teknologi sebagai keterampilan ilmiah yang berkaitan tentang pengolahan sumber informasi dalam rangka membangun pengetahuan peserta didik. Indikator digital/ICT literacy meliputi komponen mengakses, mengelola, mengintegrasi, mengevaluasi, membuat, dan mengomunikasi (CETF, 2008:3).

Data dari studi lapangan diperoleh informasi bahwa guru masih terbatas dalam memanfaatkan internet dalam proses pembelajaran (e-learning). Teknologi memungkinkan PBL, dimana peserta didik dapat menggunakan alat seperti pengolah kata, spreadsheet, dan database untuk melaksanakan tugas-tugas seperti menguraikan, penyusunan esai, menganalisis data numerik, dan melacak informasi yang dikumpulkan (Solomon, 2003:2). E-mail, milis elektronik, forum, dan aplikasi online lainnya memfasilitasi komunikasi dan kolaborasi dengan dunia di luar kelas. Saat ini penggunaan teknologi informasi dan komunikasi (ICT) terhubung dengan projectbased learning (Kubiatko \& Vaculova, 2011:68). Model Project-Based Learning merupakan model yang disarankandalam implementasi Kurikulum 2013 dengan menerapkan scientific approach yang memberikan kesempatan peserta didik untuk dapat memanfaatkan ilmu pengetahuan dan teknologi dan membentuk peserta didik yang melek ilmiah (scientific literacy) serta merupakan sebuah model pembelajaran yang sesuai dengan kerangka konstruktivis yang memandang proses pembelajaran sebagai penyelidikan aktif dan bermakna dan pengetahuan dibangun oleh peserta didik. Dimana dimensi atau aspek sebagai tema melek ilmiah (scientific literacy) mengikuti hakikat IPA yaitu pengetahuan IPA sebagaicara berpikir, pengetahuan IPA sebagai cara untuk menyelidiki, IPA sebagai tubuh pengetahuan, dan IPA dan interaksinya dengan teknologi dan masyarakat (Chiappetta \& Koballa, 2010:105).

Project-Based Learning (PjBL) dimulai dengan penugasan untuk melaksanakan satu/lebih tugas yang mengarah pada produk akhir dengan sintaks yang meliputi kegiatan mengajukan pertanyaan, merancang tahap penyelesaian proyek, menyusun jadwal pelaksanaan proyek, mengumpulkan, menganalisis, dan menafsirkan data menggunakan matematika, informasi, teknologi komputer dan berpikir komputasi, menyusun laporan dan presentasi hasil proyek serta evaluasi proses hasil proyek. PjBL bukan hanya model pembelajaran yang bertujuan untuk memperoleh pengetahuan tentang spesifik bidang isi, tapi merupakan model yang menargetkan pembangunan peserta didik secara keseluruhan (Tamim \& Grant, 2013:74). Berdasarkan beberapa hal yang telah dijelaskan sebelumnya, maka diperlukan pengembangan perangkat pembelajaran IPA berbasis project-based learning untuk membekali foundational knowledge dan meningkatkan scientific literacy peserta didik SMP.

Penelitian ini bertujuan mengetahui kelayakan dan pengaruh perangkat pembelajaran IPA berbasis project-based learning untuk membekali foundational knowledge khusus pada digital/ICT literacy dan meningkatkan scientific literacy peserta didik SMP. Dengan dilakukannya penelitian ini maka memberikan kontribusi bagi peneliti, dapat memberikan pengalaman dan menumbuhkan wawasan tentang penelitian yang nantinya dapat diaplikasi secara nyata sebagai guru IPA; bagi guru, perangkat pembelajaran yang dihasilkan dapat digunakan dalam proses pembelajaran dan dapat meningkatkan kualitas pembelajaran IPA; bagi peserta didik, penerapan perangkat pembelajaran dapat menciptakan peserta didik yang aktif dan kreatif dalam proses pembelajaran; bagi sekolah, perangkat pembelajaran yang dihasilkan dapat membantu sekolah dalam menyediakan perangkat pembelajaran IPA yang sesuai tuntutan Kurikulum 2013.

Perangkat pembelajaran IPA terdiri dari RPP, LKPD, dan instrumen penilaian yang dipersiapkan sebelum dan digunakan oleh pendidik dalam proses pembelajaran dengan tujuan untuk memperoleh pengetahuan yang terorganisir mela- 
lui pengamatan dan pengujian fakta tentang fisik alam semesta yang merupakan bagian integral dari kehidupan sehari-hari.

Project-based learning ( $\mathrm{PjBL}$ ) merupakan model pembelajaran proyek yang diawali dengan masalah dan mengarah pada produk akhir yang dihasilkan peserta didik melalui kerja sama dan partisipasi aktif dalam proses pembelajaran dengan tujuan membentuk peserta didik secara keseluruhan. Sintaks dari Project-based learning yaitu: (1) Mengajukan pertanyaan yang berasal dari fenomena disekitar, (2) Merancang tahap dalam penyelesaian proyek, (3) Menyusun jadwal pelaksanaan proyek, (4) Mengumpulkan, menganalisis serta menafsikan data menggunakan matematika, informasi, teknologi komputer dan berpikir komputasi, (5) Penyusunan laporan dan presentasi proyek, (6) Evaluasi proses dan hasil proyek.

Perangkat pembelajaran IPA berbasis project-based learning adalah RPP, LKPD, dan instrumen penilaian yang dipersiapkan sebelum dan digunakan oleh guru dalam proses pembelajaran dengan tujuan untuk memperoleh pengetahuan yang terorganisir dan membentuk peserta didik secara menyeluruh melalui model pembelajaran yang diawali dengan masalah dan mengarah pada produk akhir yang dihasilkan peserta didik melalui kerja sama dan partisipasi aktif dalam proses pembelajaran. RPP IPA berbasis project based learning yang baik mencakup syarat-syarat, sebagai berikut (adaptasi dari Mendikbud, 2013:5): memiliki identitas sekolah, mata pelajaran, kelas/ semester yang jelas; materi pokok yang dipilih sesuai dengan $\mathrm{KD}$; pengorganisasian alokasi waktu yang sesuai dengan rencana kegiatan; tujuan pembelajaran dirumuskan dengan jelas dan menggunakan kata-kata operasional meliputi ABCD (audience, behaviour, condition, dan degree) serta mencakup aspek digital/ICT literacy dan scientific literacy; materi dan metode pembelajaran.

Materidan metode pembelajaran sesuai dengan tujuan pembelajaran, KD yang dipadukan, keterpaduan antar lintas bidang kajian, tema sesuai dengan tujuan pembelajaran, tingkat perkembangan berpikir peserta didik, sesuai dengan model project-based learning serta kesesuaian materi dengan metode pembelajaran, media, alat dan sumber belajar sesuai dengan tujuan pembelajaran, sesuai dengan materi, alat dan bahan mudah untuk didapatkan, menerapkan penggunaan teknologi informasi dan komunikasi (ICT); langkah kegiatan pembelajaran sesuai dengan tujuan dan materi pembelajaran, dirancang secara jelas dan urut mulai dari pendahuluan, inti dan penutup; kesesuaian dengan scientific approach dan sesuai dengan sintaks project-based learning serta sesuai dengan alokasi waktu; penilaian dengan instrumen yang lengkap berupa authentic assessmen dan sesuai dengan tujuan pembelajaran serta sesuai dengan penilaian model project-based learning.

LKPD yang baik harus memenuhi kriteria kevalidan, kepraktisan dan keefektifan dengan indikator LKPD digital berbasis project-based learning yang dikembangkan memenuhi aspek tampilan meliputi keterbacaan tulisan, kualitas tampilan gambar, dan kesesuaian tata letak, gambar, dan komposisi warna; aspek konten meliputi kesesuaian dengan kompetensi dasar, kebenaran isi, susunan mendukung penerapan ICT dan scientific approach, berkaitan dengan kehidupan peserta didik serta sesuai dengan sintaks project-based learning; aspek kegiatan proyek meliputi keterkaitan kegiatan proyek dengan materi, kejelasan tujuan proyek, kegiatan mendorong keterbekalan digital/ICT literacy, kegiatan proyek mencakup scientific approach sehingga dapat meningkatkan scientific literacy peserta didik; dan yang terakhir aspek situs/web/ perangkat yang meliputi kemungkinan mengalami gangguan, ketepatan pemilihan template, dan kemudahan dalam pengoperasian.

Foundational knowledge merupakan satu diantara tiga kompetensi dasar yang harus diketahui peserta didik untuk memenuhi pembelajaran abad XXI sesuai dengan tuntutan Kurikulum 2013 pada penelitian ini dikhususkan pada subkategori Digital/ICT literacy adalah kemampuan dan kesadaran yang dimiliki oleh seseorang menggunakan teknologi digital (teknologi informasi dan komunikasi) secara tepat yang diperoleh melalui pembelajaran proyek (project-based learning) untuk mengakses, mengidentifikasi, mengelola, mengintegrasi, mengevaluasi, menganalisis dan mensintesis serta menciptakan informasi dalam upaya membangun pengetahuan baru yang berguna dalam kehidupan bermasyarakat.

Scientific literacy adalah kemampuan memahami pengetahuan dan konsep ilmiah serta proses yang diperlukan untuk mengambil keputusan dengan indikator seseorang yang telah memiliki literasi sains yaitu: (1) memiliki pengetahuan dan pemahaman tentang konsep dan proses 
ilmiah, (2) dapat menemukan jawaban atas rasa ingin tahu dari pengalaman sehari-hari, (3) mampu membaca dan memahami serta memberikan validitas kesimpulan terhadap artikel yang berhubungan dengan ilmu pengetahuan, (4) mampu mengevaluasi kualitas informasi ilmiah, dan (5) memiliki kemampuan untuk menunjukkan dan mengevaluasi pendapat berdasarkan bukti.

\section{METODE}

Penelitian ini merupakan penelitian pengembangan dengan model Reseach and Depelopment Borg \& Gall (1983:775) yang terdiri atas 10 tahap, yaitu (1) Research and information collecting; (2) Planning; (3) Develop preliminary form of product; (4) Preliminary field testing; (5) Main product revision; (6) Main field testing; (7) Operational product revision; (8) Operational field testing; (9) Final product revision; (10) Dissemination and implementation.

Penelitian dimulai dari bulan Januari hingga April 2015 yang bertempat di SMPN 15 Yogyakarta untuk uji coba terbatas dan SMPN 10 Pontianak untuk uji coba lapangan dengan 6 kali pertemuan masing-masing 3 jam pelajaran kelas kontrol dan 3 jam pelajaran kelas eksperimen. Subjek coba adalah peserta didik kelas VII tingkat SMP dengan rincian SMPN 15 Yogyakarta
8 peserta didik sebagai subjek coba terbatas I dan 33 peserta didik sebagai subjek coba terbatas II. Subjek coba pada SMPN 10 Pontianak 30 peserta didik sebagai subjek coba lapangan kelas eksperimen dan 28 peserta didik sebagai subjek coba lapangan kelas kontrol.

Prosedur menggunakan model Borg \& Gall dengan modifikasi yang meliputi studi pendahuluan, desain produk, validasi terdiri dari validasi ahli materi dan ahli media serta validasi empiris soal scientific literacy, ujicoba yang terdiri dari uji coba terbatas I dan II serta uji coba lapangan, dan produk akhir. Rincian prosedur penelitian yang digunakan oleh peneliti dapat dilihat pada Gambar 1 .

Data penelitian yang dikumpulkan berupa data kuantitatif-kualitatif. Instrumen yang digunakan dalam pengumpulan data berupa lembar validasi kelayakan perangkat pembelajaran IPA berbasis project-based learning, lembar observasi dan angket keterbekalan digital/ICT literacy serta soal tes ketercapaian scientific literacy peserta didik. Data hasil validasi perangkat pembelajaran dianalisis menggunakan percentage agreement sebagai berikut (Borich, 1994:385).

percentageagreement $=1-\frac{A-B}{B+A} \times 100 \%$

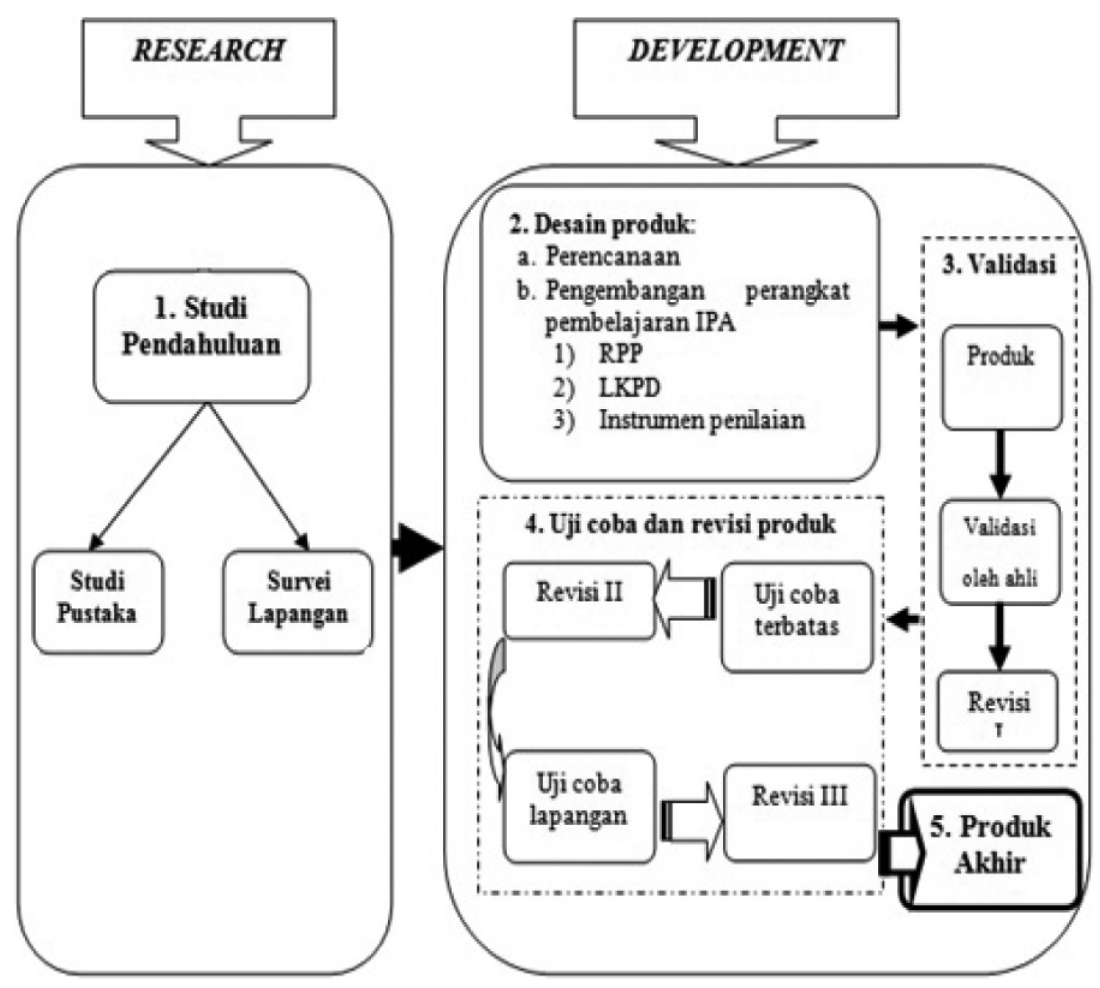

Gambar 1. Prosedur Penelitian 
Keterbekalan digital/ICT literacy dianalisis menggunakan skala Likert (skala lima), sedangkan untuk peningkatan scientific literacydianalisis menggunakan program Quest dengan rentang INFIT MNSQ validitas dari 0,77 sampai 1,30 untuk validitas butir soal.

Tabel 1. Kriteria Skala Lima

\begin{tabular}{lcc}
\hline \multicolumn{1}{c}{ Interval } & Nilai & Kriteria \\
\hline$M+1,5 \mathrm{~s}<\mathrm{X}$ & A & Baik Sekali \\
$\mathrm{M}+0,5 \mathrm{~s}<\mathrm{X} \leq \mathrm{M}+1,5 \mathrm{~s}$ & B & Baik \\
$\mathrm{M}-0,5 \mathrm{~s}<\mathrm{X} \leq \mathrm{M}+0,5 \mathrm{~s}$ & $\mathrm{C}$ & Cukup Baik \\
$\mathrm{M}-1,5 \mathrm{~s}<\mathrm{X} \leq \mathrm{M}-0,5 \mathrm{~s}$ & D & Kurang Baik \\
$\mathrm{X} \leq \mathrm{M}-, 5 \mathrm{~s}$ & E & Tidak Baik \\
\hline
\end{tabular}

(Azwar, 2002:163)

Data scientific literacy juga dianalisis menggunakan gain skor dan gain skor ternormalisasi sebagai berikut (Hake, 2007, p.8).

Program SPSS digunakan untuk melihat signifikansi pengaruh perangkat pembelajaran terhadap peningkatan scientific literacy peserta didik.

\section{HASIL DAN PEMBAHASAN Hasil}

Pengembangan produk dilakukan sesuai hasil studi pendahuluan adalah kurikulum yang digunakan di SMP N 15 Yogyakarta dan SMP N 10 Pontianak adalah Kurikulum 2013 dan mulai diterapkan sejak awal diberlakukannya Kurikulum 2013 karena merupakan sekolah pilot project. Mata pelajaran IPA yang diajarkan belum terpadu dan penguasaan konsep yang diberikan lebih pada konsep-konsep Biologi karena guru IPA yang mengajar merupakan sarjana pendidikan Biologi (SMP N 15 Yogyakarta). Pada SMP N 10 Pontianak lebih berfokus pada konsep-konsep fisika karena merupakan sarjana teknik.

Perangkat pembelajaran IPA berupa silabus mengikuti silabus yang telah disiapkan oleh pemerintah. RPP dibuat bersama MGMP yang belum disesuaikan dengan kondisi dan karakteristik sekolah. LKPD sesuai dengan buku pegangan siswa, sedangkan penilaian belum dilakukan sepenuhnya oleh guru karena terlalu kompleks. Pembelajaran IPA yang dilaksanakan sudah menerapkan scientific approach tapi lebih menekankan pada penguasaan konsep. Selain itu, model project-based learning belum seutuhnya dilaksanakan oleh guru padahal model projectbased learning merupakan model yang disarankan dalam implementasi Kurikulum 2013.

Pembelajaran IPA hanya sebatas meminta peserta didik untuk mencari informasi (browsing) di internet tanpa memperhatikan keterbekalan $d i$ gital/ICT literacy peserta didik. Scientific literacy peserta didik masih rendah. Hal ini ditunjukkan ketika guru mengajukan beberapa pertanyaan, peserta didik menjawab dengan jawaban yang bersifat konseptual dan belum bersifat aplikatif dalam pemecahan masalah.

Pengembangan produk awal berupa perangkat pembelajaran IPA berbasis project-based learning divalidasi oleh ahli yang dianggap kompeten. Hasil validasi dapat dilihat pada Gambar 2.

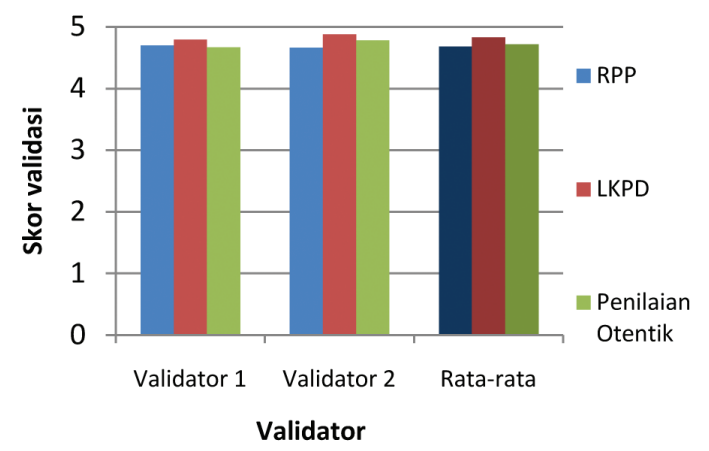

Gambar2. Histogram skor Hasil Validasi Ahli Media

Skor rata-rata untuk setiap perangkat dari RPP, LPKD, dan penilaian otentik secara berurut yaitu 4,$68 ; 4,83$; 4,72 yang jika dikonversi menjadi skala 5 diperoleh kriteria baik sekali.

Tabel 2. Kriteria Penilaian Perangkat Pembelajaran oleh Validator

\begin{tabular}{ccc}
\hline Interval & Nilai & Kriteria \\
\hline $4,00<X$ & A & Baik Sekali \\
$3,33<X \leq 4,00$ & B & Baik \\
$2,67<X \leq 3,33$ & C & Cukup Baik \\
$2,00<X \leq 2,67$ & D & Kurang Baik \\
$X \leq 2,00$ & E & Tidak Baik \\
\hline
\end{tabular}

Selain divalidasi oleh ahli materi, perangkat pembelajaran juga divalidasi oleh ahli media dengan hasil validasi disajikan pada Gambar 3. Pada Gambar 3 diketahui bahwa rata-rata penilaian perangkat pembelajaran IPA oleh validator ahli media sebesar 4,33 dengan kriteria baik sekali. 


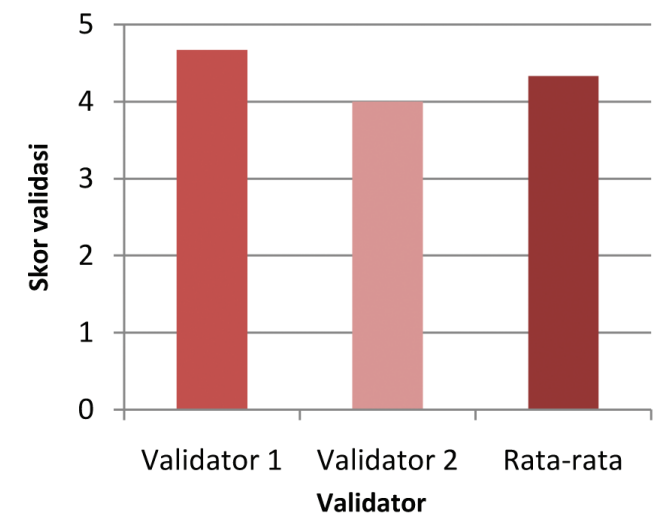

Gambar 3. Histogram Skor Validasi Ahli Media

Berdasarkan hasil validasi ahli materi dan ahli media dapat ditentukan persentase kesepakatan yang dikenal dengan percentage agreement yang hasil perhitungannya disajikan pada Tabel 3.

Tabel 3. Hasil Percentage Agreement

\begin{tabular}{lccc}
\hline $\begin{array}{c}\text { Produk } \\
\text { yang } \\
\text { divalidasi }\end{array}$ & $\begin{array}{c}\text { Validator } \\
1\end{array}$ & $\begin{array}{c}\text { Validator } \\
2\end{array}$ & $\begin{array}{c}P A \\
(\%)\end{array}$ \\
\hline RPP & 4,70 & 4,66 & 99,57 \\
LKPD & 4,73 & 4,44 & 96,82 \\
Penilaian Otentik & 4,67 & 4,78 & 98,82 \\
\hline Rata-rata & & & 98,41 \\
\hline
\end{tabular}

Percentage agreement perangkat pembelajaran IPA berbasis project-based learning sebesar 98,41\% dengan kriteria baik sekali sehingga perangkat pembelajaran yang dikembangkan layak untuk digunakan pada peserta didik tingkat Sekolah Menengah Pertama.

Uji empiris dilakukan pada soal tes $s c i$ entific literacy yang berjumlah 25 butir soal dengan INFIT MNSQ butir yang valid berada pada rentang 0,77 sampai 1,30 . Hasil yang diperoleh berupa 21 soal valid dan 3 soal yang terdiri dari item 1, 13, 22, dan 24 memperoleh hasil perfect question sehingga perlu dilakukan revisi terhadap pernyataan dan distraktor soal. Uji coba terbatas terdiri dari uji coba terbatas I dan II. Uji coba terbatas I berupa uji keterbacaan LKPD terhadap 8 peserta didik kelas VII di SMPN 15 Yogyakarta. Hasil uji coba terbatas I disajikan pada Tabel 5 Berdasarkan Tabel 4 diketahui bahwa hasil keterbacaan LKPD yang dilihat dari aspek konten, website, kebahasaan, dan tampilan berada pada kriteria baik sekali. Uji keterbacaan dilakukan untuk mengetahui keefektifan bahasa dan navigasi website yang akan digunakan oleh peserta didik dalam proses pembelajaran sehingga berbagai kemungkinan buruk dapat diminimalisir terjadi pada saat uji coba lapangan.

Tabel 4. Hasil Keterbacaan LKPD

\begin{tabular}{|c|c|c|c|}
\hline No. & Aspek & Rata-rata & Kriteria \\
\hline & Konten & 4,83 & \\
\hline 2. & Website & & \\
\hline 3. & Kebaha & 4,69 & Sekali \\
\hline 4. & Tampilan & 4,53 & Baik Sekali \\
\hline
\end{tabular}

Uji coba terbatas II berupa pelaksanaan proses pembelajaran menggunakan perangkat pembelajaran berbasis project-based learning yang telah direvisi mulai dari pretes hingga posttes pada 33 peserta didik kelas VII SMPN 15 Yogyakarta. Persentase keterlaksanaan RPP pada tahap uji coba terbatas II dapat dilihat pada Tabel 5.

Tabel 5. Persentase Keterlaksanaan RPP

\begin{tabular}{cc}
\hline Pertemuan ke- & Keterlaksanaan (\%) \\
\hline I & 94,44 \\
II & 82,22 \\
III & 80,56 \\
\hline
\end{tabular}

Rata-rata keterlaksanaan RPP sebesar $85,74 \%$. Keterbekalan digital/ICT literacy pada uji coba terbatas II diperoleh rata-rata skor keterbekalan sebesar 96,92\%.

Keterbekalan digital/ICT literacy peserta didik dapat dilihat dari persentase keamjuan peserta didik dalam melaksanakan tugas yang diberikan melalui website. Perolehan rata-rata persentase kemajuan kerterbekalan peserta didik sebesar $88,90 \%$ yang berada pada kriteria baik sekali. Rincian keterbekalan untuk setiap aspek digital/ICT literacy dapat dilihat pada Gambar 4.

Perolehan keterbekalan untuk aspek akses sebesar $90,61 \%$, mengelola sebesar $100 \%$, mengintegrasi $90,91 \%$, mengevaluasi, membuat dan mengkomunikasikan sebesar $100 \%$. Persentase keterbekalan digital/ICT literacy tersebut dapat dikategorikan ke dalam kriteria baik sekali. 


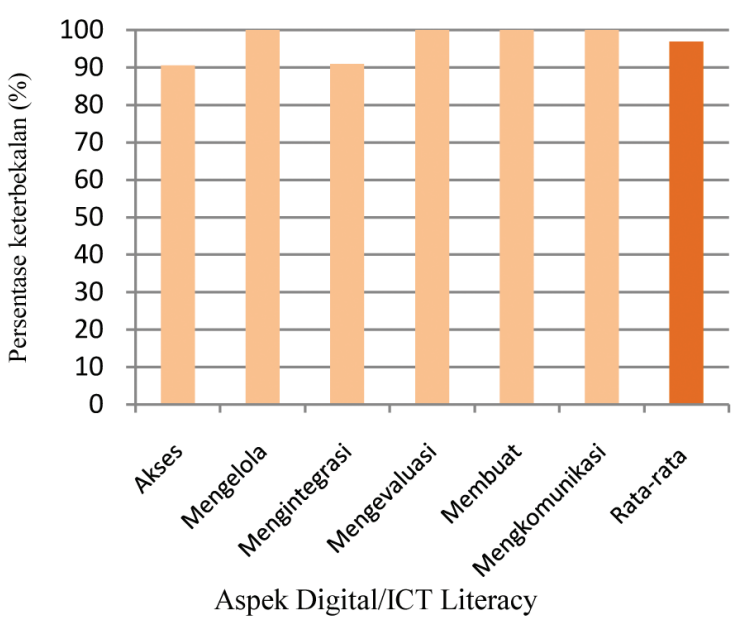

Gambar 4. Histogram Persentase Keterbekalan Digital/ICT Literacy Uji Coba Terbatas II

Hasil pencapaian scientific literacy peserta didik pada tahap uji coba terbatas II disajikan pada Gambar 5. Berdasarkan Gambar 5 diketahui bahwa rata-rata skor pretes 63,75 berada pada kriteria baik dan rata-rata skor posttes 76,14 berada pada kriteria baik sekali dengan perolehan gain skor untuk pencapaian scientific literacy sebesar $12,39 \%$.

Standar deviasi scientific literacy untuk pretes sebesar 16,67 dan untuk posttes sebesar 9,14 dengan selisih sebesar 7,55. Hal ini menunjukkan bahwa pencapaian scientific literacy pada uji coba terbatas II berada pada kriteria baik sekali.

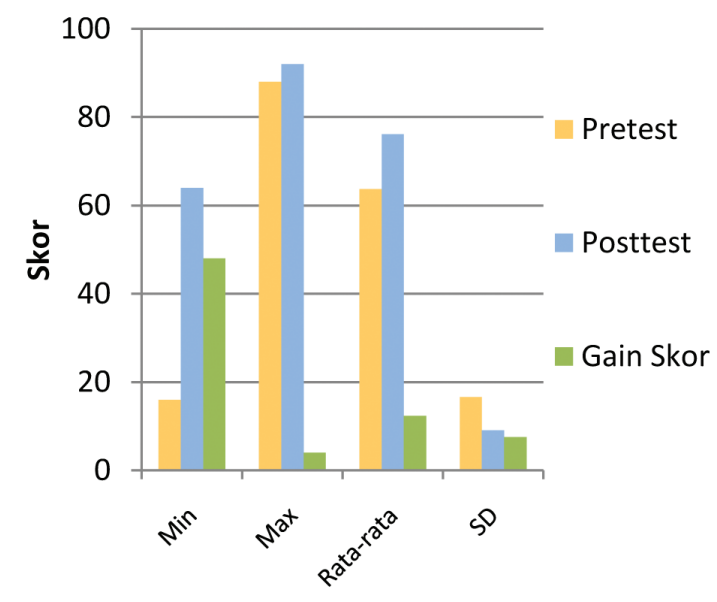

Kriteria

Gambar 5. Histogram Skor Hasil Scientific Literacy Uji Coba Terbatas II

Pada tahap uji coba lapangan dilakukan dengan menggunakan kelas kontrol dan kelas ekperimen pada SMPN 10 Pontianak. Pemilihan
SMPN 10 Pontianak karena memiliki karakteristik dan memiliki rentang nilai yang hampir sama dengan SMPN 15 Yogyakarta yang menjadi tempat pelaksanaan uji coba terbatas. Rata-rata nilai pada SMPN 15 Yogyakarta sebesar 26,13 dan SMPN 10 Pontianak sebesar 25,18. Hal ini menunjukkan bahwa terdapat selisih nilai 0,95 antara SMPN 15 Yogyakarta dengan SMPN 10 Pontianak.

Persentase keterlaksanaan RPP pada tahap uji coba lapangan dapat dilihat pada Tabel 6. Pada Tabel 6 diketahui rata-rata persentase keterlaksanaan RPP sebesar $86,11 \%$. Jika dikonversi pada skala 5 maka berada pada kriteria baik sekali.

Tabel 6. Persentase Keterlaksanaan RPP

\begin{tabular}{cc}
\hline Pertemuan ke- & Keterlaksanaan (\%) \\
\hline I & 88,89 \\
II & 83,33 \\
III & 86,11 \\
\hline
\end{tabular}

Keterbekalan digital/ICT literacy peserta didik dapat dilihat dari persentase kemajuan peserta didik dalam melaksanakan tugas yang diberikan melalui website. Perolehan rata-rata persentase kemajuan kerterbekalan peserta didik sebesar $84,58 \%$ berada pada kriteria baik sekali. Selain itu, Keterbekalan digital/ICT literacy pada uji coba lapangan untuk setiap aspek diperoleh rata-rata keterbekalan sebesar 98,29\% dengan rincian setiap aspek digital/ICT literacy dapat dilihat pada Gambar 6 dengan rata-rata keterbekalan digital/ICT literacy diperoleh kriteria baik sekali.

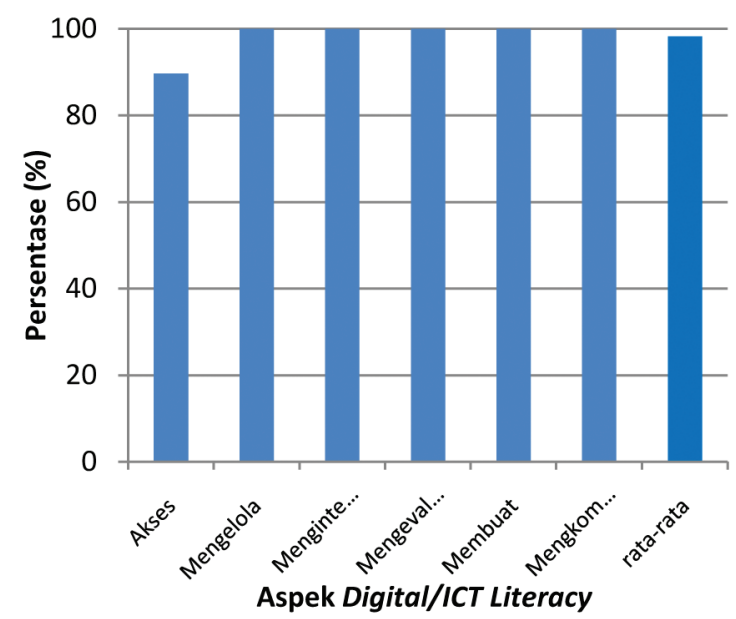

Gambar 6. Histogram Persentase Keterbekalan Digital/ICT Literacy Peserta Didik Ujicoba Lapangan 
Hasil gain skor dan skor ternormalisasi ketercapaian scientific literacy peserta didik pada uji coba lapangan dapat dilihat pada Tabel 7.

Rata-rata gain skor kelas kontrol 1,14 dengan gain ternormalisasi sebesar 0,03 jika dibandingkan pada kriteria Hake (2007, p.8) yang terdapat pada Tabel 8 maka gain ternormalisasi kelas kontrol dapat dikategorikan pada kriteria rendah.

Tabel 7. Skor Pencapaian Scientific Literacy Peserta Didik Uji Coba Lapangan

\begin{tabular}{lcccc}
\hline \multirow{2}{*}{ Kriteria } & \multicolumn{2}{c}{ Kontrol } & \multicolumn{2}{c}{ Eksperimen } \\
\cline { 2 - 5 } & $\begin{array}{c}\text { Gain } \\
\text { skor }\end{array}$ & N-Gain & $\begin{array}{c}\text { Gain } \\
\text { skor }\end{array}$ & N-Gain \\
\hline Min & 4,00 & 0,06 & 27,00 & 0,38 \\
Max & 0,00 & 0,00 & 16,00 & 0,67 \\
Rata-rata & 1,14 & 0,03 & 15,37 & 0,37 \\
SD & 2,89 & 0,03 & 0,74 & 0,01 \\
\hline
\end{tabular}

Pada kelas eksperimen diperoleh gain skor sebesar 15,37 dengan gain ternormalisasi sebesar 0,37 berada pada kriteria sedang.

Tabel 8. Gain Skor Ternormalisasi

\begin{tabular}{cc}
\hline $\begin{array}{c}\text { Gain skor Ternormalisasi } \\
(\mathrm{N}-\text { Gain } /<\mathrm{g}>)\end{array}$ & Kriteria \\
\hline $0,70 \leq \mathrm{g}<1,00$ & Tinggi \\
$0,30 \leq \mathrm{g}<0,70$ & Sedang \\
$\mathrm{g}<0,30$ & Rendah \\
\hline
\end{tabular}

Uji normalitas dilakukan pada perolehan gain skor berdasarkan data uji coba lapangan. Nilai sig yang diperoleh pada uji normalitas sebesar 0,151 (Kolmogorov-Smirnov) dan 0,457 (Shapiro-Wilk) untuk kelas kontrol. Nilai sig pada kelas eksperimen sebesar 0,200 (KolmogorovSmirnov) dan 0,656 (Shapiro-Wilk). Nilai sig. uji normalitas diperoleh nilai sig $>0,05$ sehingga dapat dikatakan bahwa data gain skor kelas eksperimen dan kelas kontrol berdistribusi normal. Uji homogenitas disajikan pada Tabel 9 dan diperoleh nilai sig sebesar $0,275>0,05$ sehingga dapat disimpulkan bahwa data gain skor kelas kontrol dan eksperimen homogen.
Tabel 9. Hasil Uji Homogenitas

\begin{tabular}{lccccc}
\hline \multicolumn{1}{c}{ Gain Score } & $\begin{array}{c}\text { Levene } \\
\text { Statistic }\end{array}$ & df1 & df2 & Sig. \\
\hline Based on Mean & 1,217 & 1 & 56 & 0,275 \\
Based on Median & 1,300 & 1 & 56 & 0,259 \\
$\begin{array}{l}\text { Based on Median and } \\
\text { with adjusted df }\end{array}$ & 1,300 & 1 & 56 & 0,260 \\
Based on trimmed mean & 1,236 & 1 & 56 & 0,271 \\
\hline
\end{tabular}

Setelah data memenuhi prasyarat awal berupa normalitas dan homogenitas dilanjutkan dengan uji Independent-Samples $t$ Test dengan hipotesis sebagai berikut.

Ho: rata-rata gain skor antara kelas kontrol dan eksperimen adalah sama

$\mathrm{H}_{1}$ : rata-rata gain skor antara kelas kontrol dan eksperimen adalah tidak sama

Hasil yang diperoleh nilai sig sebesar 0,000 $<0,005$ yang berarti bahwa rata-rata gain skor antara kelas kontrol dan kelas eksperimen tidak sama. Perbedaan gain skor ditunjukkan dengan nilai mean kelas eksperimen sebesar 15,5333 sedangkan kelas kontrol hanya 1,1429. Hal ini menunjukkan bahwa pembelajaan yang menggunakan perangkat pembelajaran IPA berbasis project-based learning dapat meningkatkan scientific literacy peserta didik SMP.

\section{Pembahasan}

Produk akhir yang dikembangkan adalah perangkat pembelajaran IPA berbasis projectbased learning yang telah dianalisis dari kajian teori, kebutuhan lapangan serta kajian penelitian yang telah dilakukan. Gambaran umum terkait produk yang dikembangkan yaitu perangkat yang dikembangkan terdiri atas tiga komponen berupa RPP, LKPD, dan penilaian otentik dimana setiap komponen tercermin karakteristik model projectbased learning sekaligus diiringi dengan kegiatan yang dapat membekali peserta didik untuk dapat memiliki keterampilan abad XXI seperti foundational knowledge khusus pada digital/ICT literacy serta mendukung tercapainya peserta didik yang melek ilmiah (scientific literacy).

Hal ini sebagaimana dijelaskan The Educational Testing Service (ETS) dalam publikasinya di Digital Transformation: A Literacy Framework for ICT Literacy (2007:15), bahwa keterampilan abad XXI "as the ability to a) collect and/or retrieve information, b) organize and manage 
information, c) evaluate the quality, relevance, and usefulness of information, and d) generate accurate information through the use of existing resources" Keterampilan abad XXI merupakan kemampuanuntuk a) mengumpulkan dan/atau mengambil informasi, b) mengatur dan mengelola informasi, c) mengevaluasi kualitas, relevansi, dan kegunaan dari informasi, dan d) menghasilkan informasi yang akurat melalui penggunaan sumber daya yang ada.

Rencana Pelaksanaan Pembelajaran yang dikembangkan terdiri dari tiga pertemuan dengan menerapkan sintaks project-based learning pada setiap pertemuan secara berkelanjutan. Setiap pertemuan mengharuskan peserta didik untuk dapat mengakses website yang telah disediakan oleh guru yaitu www.sciencertm.edu20.orgdalam upaya membekali digital/ICT literacy peserta didik dengan meminta peserta didik melakukan berbagai kegiatan seperti mengakses, mengerjakan berbagai latihan soal yang berkaitan dengan materi yang telah disampaikan. Selama pembelajaran peserta didik diajak untuk menemukan masalah dari kehidupan sehari-hari terkait materi yang berujung pada produk akhir yang dihasilkan peserta didik serta diminta untuk dapat terampil menggunakan peralatan teknologi informasi dan komunikasi seperti penggunaan handphone sebagai sarana belajar, penggunaan kamera untuk mendokumentasikan kegiatan serta penggunaan laptop/komputer untuk membuat laporan proyek sesuai dengan metode ilmiah (scientific method). Pembelajaran seperti ini sesuai dengan penjelasan dari Nagl et al (2012:85)"...teaching is not oriented to content, whose adoption allows the student to cope in the same or similar situations, but the method of their application in an unfamiliar situation allows the student to solve the problem". Makna dari RPP hasil pengembangan memandu guru, bahwa mengajar tidak berorientasi pada konten, mengajar memungkinkan peserta didik menghadapi situasi yang sama atau serupa, namun metode penerapannya dalam situasi yang berbeda, sehingga memungkinkan peserta didik mampu memecahkan masalah

Websitewww.sciencertm.edu20.org membantu guru dalam memberikan penilaian sesuai dengan tuntuan Kurikulum 2013 karena merekapitulasi nilai peserta didik sesuai dengan grade yang telah ditentukan sebelumnya. Penggunaan website tersebut tidak dapat diakses oleh publik yang berarti bahwa setiap peserta didik memiliki akun masing-masing untuk dapat mengakses materi, informasi, pengetahuan, tugas, bahkan dapat mengetahui nilai yang mereka peroleh dari setiap tugas yang telah dikerjakan secara langsung.

Lembar Kegiatan Peserta Didik dirancang sesuai dengan komponen yang harus terdapat dalam LKPD kegiatan proyek yang akan dikerjakan oleh peserta didik. Komponen tersebut terdiri dari lembar penjelasan, prosedur proyek, lembar analisis, lembar kesimpulan, dan laporan proyek dengan tetap mencerminkan sintaks project-based learning.LKPD yang dihasilkan dalam penelitian ini didukung oleh Cakiki et al (2013:11) yang menyatakan "...project-based science teaching as a useful pedagogical strategy enabling students to improve meaningful learning and to make connections between their real-life experiences and new information. Kegiatan proyek yang dilakukan peserta didik membuat pembelajaran menjadi bermakna dan membuat keterkaitan antara pengalaman hidup nyata dengan informasi baru,

Penilaian otentik yang dikembangkan berupa penilaian proyek, penilaian pengetahuan scientific literacy, serta penilaian keterampilan digital/ICT literacy sekaligus penilaian antar teman yang menjadi informasi tambahan bagi guru untuk mengetahui peserta didik yang mengerjakan tugas dengan maksimal dan tidak. Pentingnya penilaian scientific literacy dalam pembelajaran IPA sebagaimana dijelaskan Holbrook dan Rannikmae (2009), bahwa penilaian scientific literacy mencakup kemampuan: intellectual (Higher Order Thinking Skills); attitudinal; societal; and interdisciplinary.

\section{SIMPULAN}

Perangkat pembelajaran IPA berbasis project-based learning yang dikembangkan berupa RPP, LKPD, dan penilaian otentik layak digunakan dengan kriteria baik sekali sesuai dengan hasil validasi serta uji coba dalam proses pembelajaran IPA tingkat SMP. Perangkat pembelajaran yang dikembangkan dapat membekali foundational knowledge peserta didik khusus pada digital/ICT literacydengan kriteria baik sekali serta dapat memfasilitasi peserta didik untuk meningkatkan scientific literacy peserta didik SMP yang ditunjukkan dengan hasil uji independent-sampel t test yang sig $>0,005$. 


\section{UCAPAN TERIMA KASIH}

Ucapan terima kasih disampaikan kepada semua pihak yang telah membantu terlaksananya penelitian ini.

\section{DAFTAR PUSTAKA}

Azwar, S. 2002. Tes Prestasi. Yogyakarta: Pustaka Belajar.

Borg, W. R., \& Gall, M. D. 1983. Educational Research (4 ed.). New York: Logman Inc.

Borich, G. D. 1994. Observation Skills for Effective Teaching. New York: Macmillan Publishing Company.

Cakiki, Y. dan Turkmen, N. 2013. An Investigation of the Effect of Project-Based Learning Approach on Children's Achievement and Attitude in Science. TOJSAT 3 (2) April 2013. 9-17

CETF. 2008. California ICT Digital Literacy: Assessments and Curriculum Framework. California: California Emerging Technology Fund by Kempster.

Chiappetta, E. L \& Koballa, T. R., Jr. 2010. Science Intruction in the Middle and Secondary Schools (7 ed.). New York: Pearson Education, Inc.

Hake, R. R. 2007. Design-Based Research in Physics Education. Diakses tanggal 10 Mei 2014 dari http://www.physics.indiana. edu/ hake/DBR Physics3.pdf.

Holbrook, J. \& Rannilmae, M. 2009. The Meaning of Scientific Literacy. International Journal of Environmental \& Science Education, 4 (3) July 2009, 275-288
Kereluik, K., Mishra, P., Fahnoe, C., \& Terry L. 2013. What Knowledge is of Most Worth: Teacher Knowledge for 21st Century Learning. Journal of Digital Learning in Teacher Education, 29 (4), 127-140.

Kubiatko, M., \& Vaculova, I. 2011. Project-Based Learning: Characteristic and the Experiences with Application in the Science Subjects. Energy Education Science and Technology Part B: Social and Educational Studies, 3 (1), 65-74.

Mendikbud. 2013. Peraturan Menteri Pendidikan dan Kebudayaan RI Nomor 65, Tahun 2013, tentang Standar Proses Pendidikan Dasar dan Menengah.

Nagl, N.G., Obadovic, D.Z., Segedinac, M.2012. Effective Teaching of Physics and Scientific methods. TEM Journal 1 (2) 2012 85-89.

Solomon, G. 2003. Project-based learning: a primer. Technology \& Learning, 23 (6), $1-3$.

Tamim, S. R., \& Grant, M. M. 2013. Definitions and Uses: Case Study of Teachers Implementing Project-Based Learning. Interdisciplinary Journal of Problem-based Learning, 7 (2), 72-101.

The Educational Testing Service (ETS).2007.A Literacy Framework for ICT Literacy $21^{\text {st }}$ Century Skills for Students and Teachers. Digital Transformation. 